University of Nebraska - Lincoln

DigitalCommons@University of Nebraska - Lincoln

Faculty Publications from the Harold W. Manter Laboratory of Parasitology

$12-1-2006$

\title{
Tadaridanema delicatus (Schwartz, 1927) n. gen., n. comb. (Trichostrongylina: Molineidae) Parasite of Molossidae Bats
}

Jorge Falcon-Ordaz

Universidad Nacional Autonoma de Mexico, falcon_jorge@terra.com.mx

Carmen Guzman-Cornejo

Universidad Nacional Autonoma de Mexico, cguzman@ibiologia.unam.mx

Luis Garcia-Prieto

Universidad Nacional Autonoma de Mexico, gprieto@ibiologia.unam.mx

Scott Lyell Gardner

University of Nebraska - Lincoln, slg@unl.edu

Follow this and additional works at: https://digitalcommons.unl.edu/parasitologyfacpubs

Part of the Parasitology Commons

Falcon-Ordaz, Jorge; Guzman-Cornejo, Carmen; Garcia-Prieto, Luis; and Gardner, Scott Lyell,

"Tadaridanema delicatus (Schwartz, 1927) n. gen., n. comb. (Trichostrongylina: Molineidae) Parasite of Molossidae Bats" (2006). Faculty Publications from the Harold W. Manter Laboratory of Parasitology. 38. https://digitalcommons.unl.edu/parasitologyfacpubs/38

This Article is brought to you for free and open access by the Parasitology, Harold W. Manter Laboratory of at DigitalCommons@University of Nebraska - Lincoln. It has been accepted for inclusion in Faculty Publications from the Harold W. Manter Laboratory of Parasitology by an authorized administrator of DigitalCommons@University of Nebraska - Lincoln. 


\title{
TADARIDANEMA DELICATUS (SCHWARTZ, 1927) N. GEN., N. COMB. (TRICHOSTRONGYLINA: MOLINEIDAE) PARASITE OF MOLOSSIDAE BATS
}

\author{
Jorge Falcón-Ordaz, Carmen Guzmán-Cornejo, ${ }^{*}$ Luis García-Prieto, $†$ and Scott Lyell Gardnerł \\ Laboratorio de Helmintología, Instituto de Biología, UNAM, Ap. Postal 70-153, C.P. 04510, México, D.F., México. e-mail: \\ gprieto@ibiologia.unam.mx
}

\begin{abstract}
On the basis of the revision of the type material of Anoplostrongylus delicatus Schwartz, 1927, and new specimens collected from Tadarida brasiliensis mexicana (Saussure, 1860) in 4 arid localities from Mexico, we describe a new genus (Tadaridanema $\mathrm{n}$. gen.), to which A. delicatus is transferred (as Tadaridanema delicatus (Schwartz, 1927) n. gen., n. comb.). This new genus differs from all other genera included in Anoplostrongylinae by having ray 2 larger than ray 3. In addition, $T$. delicatus can be differentiated from the type species of Anoplostrongylus (Anoplostrongylus paradoxus (Travassos, 1918)) because it possess vestibular branches equal in length, cephalic inflation divided into 2 regions, and synlophe with many small ridges at the midbody level, whereas in T. delicatus, vestibular branches are equal in size, cephalic inflation is simple in structure, and the synlophe has only 2 well-developed dorsal cuticular ridges.
\end{abstract}

Anoplostrongylus delicatus Schwartz, 1927, parasitizes species of bats in Tadarida Rafinesque, 1814, and Molossus Geoffroy, 1805 (Table I); this species was described by Schwartz (1927) from an unidentified bat in Texas; later, Travassos (1937) transferred it to Molinostrongylus Skarbilovitch, 1934. However, Durette-Desset and Chabaud (1975) pointed out that $A$. delicatus does not exhibit the diagnostic features of Molinostrongylus sp. and recommended it should be kept in Anoplostrongylus Boulenger, 1926. On the basis of the revision of the type material of this nematode species and of new specimens collected from Tadarida brasiliensis mexicana (Saussure, 1860) in 4 arid localities from Mexico (Guzmán-Cornejo et al., 2003), we conclude that $A$. delicatus belongs in a new genus, which is described herein.

\section{MATERIAL AND METHODS}

Between November 1996 and April 1998, 96 specimens of T. brasiliensis mexicana were collected with the use of mist nets from 4 arid regions of Mexico: Cueva de la Boca, Santiago, Nuevo León; Fábrica la Constancia, Nombre de Dios, Durango; Iglesia de Guadalupe Garzarón, Concepción del Oro, Zacatecas; and Río Salado, Zapotitlán de las Salinas, Puebla. Hosts were killed by an overdose of sodium pentobarbital; worms collected were fixed in boiling $70 \%$ ethanol. Specimens were cleared with Ammans lactophenol and temporarily mounted for morphological study. Bats were deposited in the Colección de Mamíferos at Museo de Zoología, Facultad de Ciencias, Universidad Nacional Autónoma de México (UNAM), Mexico City.

For a detailed description of the synlophe, cross sections were made (at the anterior, middle, and posterior regions of the body of A. delicatus) following Durette-Desset (1985) and mounted in face view. Specimens were deposited in the Colección Nacional de Helmintos (CNHE), UNAM, Mexico City; the Harold W. Manter Laboratory of Parasitology (HWML), Lincoln, Nebraska; and the U.S. National Parasite Collection (USNPC), Beltsville, Maryland. For comparative purposes, the following specimens were examined: A. delicatus (USNPC 027138, 05486, 054861) and Molinostrongylus delicatus (Schwartz, 1927) Travassos, 1937 (HWML 37516, 37517, 37518).

Measurements were taken with a micrometer ocular and presented as the range, with means, standard deviation, and sample size in brackets, and were expressed in micrometers unless otherwise stated. Figures were drawn with the aid of a drawing tube. Measurements of the holotype and allotype are in parentheses.

Received 22 September 2005; revised 16 February 2006; accepted 17 February 2006.

* Laboratorio de Acarología, Instituto de Biología, UNAM, Ap. Postal 70-153, C.P. 04510, México, D.F., México.

† To whom correspondence should be addressed.

$\ddagger$ Harold W. Manter Laboratory of Parasitology, University of Nebraska-Lincoln, Lincoln, Nebraska 68588-0514.

\section{DESCRIPTION}

Tadaridanema n. gen.

Diagnosis: Molinoidea, Molineidae, Anoplostrongylinae. Nematodes of medium size coiled loosely, females larger than males. Lips absent. Cephalic inflation almost undivided. Nerve ring located at middle of esophagus; excretory pore opening posterior to nerve ring. Synlophe with 2 great dorsal cuticular ridges in the middle of body. Longitudinal ridges extend posteriorly from border of cephalic inflation to just anterior to caudal extremity. Males with well-developed and symmetrical copulatory bursa; ray 2 larger than ray 3. Rays 4,5 , and 6 separated, straight, and with striated cuticle. Tail of female with an ending tip surrounded by 3 conical cuticular processes; uterine branches unequal.

\section{Taxonomic summary}

Type and only known species: Tadaridanema delicatus (Schwartz, 1927) n. comb. from the intestine of an unidentified bat from Texas; other records in Molossidae bats from California, Florida, Louisiana, and New Mexico and from the Mexican states of Durango, Nuevo León, Puebla, Sinaloa, and Zacatecas.

Etymology: The generic name refers to the fact that the nematode occurs basically in bats of Tadarida spp.

\section{Remarks}

Following Durett-Desset (1983), our specimens are included in Molineidae: Anoplostrongylinae by having a caudal spine surrounded by 3 tubercles, a dorsal ray not divided at the base, and synlophe with ridges directed from ventral to dorsal side and for parasitizing New World bats. This subfamily comprises 23 genera distributed worldwide (Durette-Desset, 1983; Vaucher and Durette-Desset, 1986; Durette-Desset and Vaucher, 1996). The new genus differs from all other genera included in Anoplostrongylinae by possessing ray 2 larger than ray 3. In addition, Tadaridanema can be distinguished from 13 of the 23 genera by possessing a caudal spine surrounded by 3 tubercles instead of 2 digitiform caudal mucrones (as in Bidigiticauda Chitwood, 1938) (Chitwood, 1938); a short tail sharply pointed, without tubercles (as in Delicata Travassos, 1935; Graphidiops Lent and Teixeira de Freitas, 1938; Paragraphidium Teixeira de Freitas and Mendonça, 1959; and Spinostrongylus Travassos, 1935) (Travassos, 1935a, 1935b; Lent and Teixeira de Freitas, 1938; Teixeira de Freitas and Mendonça, 1959); a tail lacking a terminal spine (as in Caenostrongylus Lent and Teixeira de Freitas, 1938, and Maciela Travassos, 1935) (Travassos, 1935a, Lent and Teixeira de Freitas, 1938); a tail with 2 ventral prominences and a dorsal spine at its truncate extremity (as in Fontesia Travassos, 1928) (Travassos, 1928); a tail conical and short (as in Trichohelix Ortlepp, 1922; Trifurcata Schulz, 1926; and Filicapitis Travassos, 1950) (Ortlepp, 1922; Schulz, 1926; Travassos, 1950); a conical and elongated tail (as in Moennigia Travassos, 1935) (Travassos, 1935a); or a bluntly rounded tail (as in Cheiropteronema Sandground, 1929) (Sandground, 1929). Likewise, the new genus differs from Delicata, Fontesia, and Maciela because they possess vestibular branches of equal size (instead of unequal branches as in Tadaridanema). The bilobed bursa present in the new genus distinguishes it from Cheiropteronema, Filicapitis, 
TABLE I. Previous records of Tadaridanema delicatus (Schwartz, 1927) n. gen., n. comb.

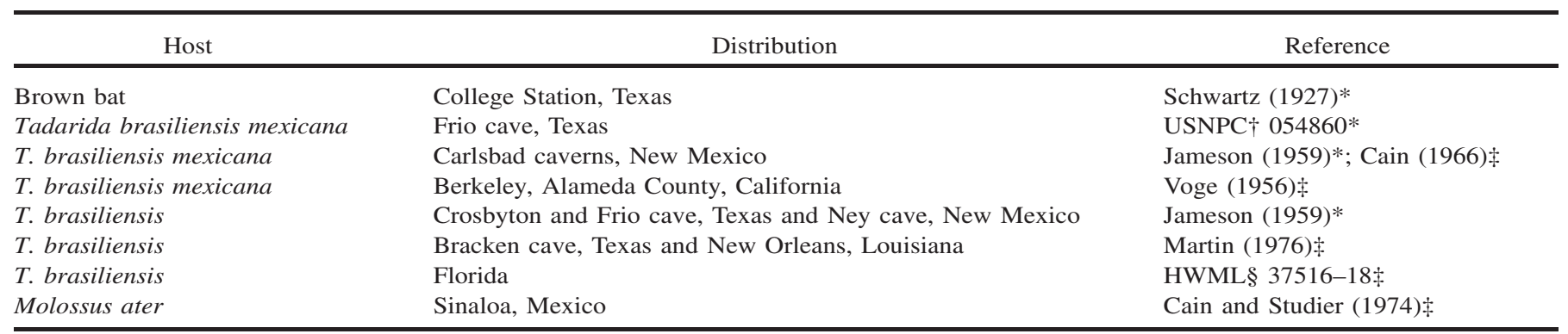

* Recorded as Anoplostrongylus delicatus.

† Specimens deposited in the U.S. National Parasite Collection, Beltsville, Maryland.

$\ddagger$ Recorded as Molinostrongylus delicatus.

$\S$ Specimens deposited in the Harold W. Manter Laboratory of Parasitology, University of Nebraska, Lincoln.

Graphidiops, Moennigia, Paragraphidium, Spinostrongylus, and Trifurcata, all of which posses trilobed bursa. In addition, Caenostrongylus and Trichohelix can be differentiated from Tadaridanema because they possess spicules ending in 2 points, whereas spicules have a pointed tip in the new genus. Finally, species of Bidigiticauda are readily distinguishable from species of Tadaridanema by the bursal dimensions (smaller than in the new genus) and because species of Chitwood's genus lack gubernaculum.

The new genus is similar to Anoplostrongylus Boulenger, 1926; Biacantha Wolfgang, 1954; Bradypostrongylus Price, 1928; Histiostrongylus Molin, 1861; Linustrongylus Vaucher and Durette-Desset, 1986; Molostrongylus Durette-Desset and Vaucher, 1996; Parahistiostrongylus Pérez-Vigueras, 1941; Torrestrongylus Pérez-Vigueras, 1935; Tricholeiperia Travassos, 1935; and Websternema (Webster, 1971), which also exhibit caudal spine surrounded by 3 tubercles. Notwithstanding, Histiostrongylus, Parahistiostrongylus, Biacantha, Websternema, and Linustrongylus can be differentiated from Tadaridanema by possessing cuticular spines on the cephalic inflation (Travassos, 1937; Pérez-Vigueras, 1941; Wolfgang, 1954; Vaucher and Durette-Desset, 1986), which are absent in the new genus. Likewise, the first 4 genera can be distinguished by having synlophe with many small ridges in the midregion, instead of 2 dorsal cuticular ridges as in Tadaridanema; moreover, species of Linustrongylus lack synlophe.

From the remaining 5 genera, which also lack cuticular spines in the cephalic region, Tadaridanema can be differentiated by the following characters: from Torrestrongylus and Tricholeiperia because they have spicules divided at the distal end (instead of having distal tip pointed as in the new genus) and ray 2 shorter than ray 3 (whereas in Tadaridanema, the length of these rays is inverted). In addition, Tricholeiperia lacks a gubernaculum and Torrestrongylus possesses a trifurcated dorsal ray (Pérez-Vigueras, 1935; Travassos, 1935b). The presence of spines in the ovejector region and the similar size of the vestibular branches and of rays 2 and 3 of the bursa are diagnostic features of Molostrongylus (Durette-Desset and Vaucher, 1996), which also distinguishes it from the new genus.

Tadaridanema most closely resembles species in Bradypostrongylus and Anoplostrongylus. Notwithstanding, species of Bradypostrongylus are distinguished from $T$. delicatus by the following characteristics: (1) synlophe with 2 great and 2 small dorsal cuticular ridges in the middle of the body compared with synlophe with only 2 great dorsal cuticular ridges in the same region in Tadaridanema (Figs. 1-3, 6); (2) dorsal ray large (vs. short in the new genus); (3) extremities of ray 8 crossing ray 9 (instead of not overlapping on those rays as in Tadaridanema; Figs. 11, 13); (4) vestibular branches equal in length in Bradypostrongylus panamensis Price, 1928, and B. inflatus (Molin, 1861), whereas T. delicatus has vestibular branches unequal; (5) spicules twisted with a relatively long twisted median process, instead of spicules simple in structure (Figs. 14, 15); and (6) tail of female ending in a slender filamentous tip, larger than tubercular process, whereas in Tadaridanema, both structures have similar size (Figs. 19, 20; Price, 1928; Guerrero, 1982; Durette-Desset, 1985).

Anoplostrongylus share several traits with Tadaridanema (i.e., both possess a short bifurcate dorsal ray, with ray 9 always shorter than ray
10 and rays 3 and 4 larger than ray 5). Likewise, the 2 genera have a well-developed gubernaculum and parasitize New World bats (Travassos, 1921; Boulenger, 1926). Notwithstanding, the monotypic Anoplostrongylus differs from Tadaridanema by possessing rays 2 and 3 almost straight and being similar in size, whereas in the new genus, these rays are curved and ray 2 is larger than ray 3 (Figs. 12, 13). In addition, vestibular branches in Anoplostrongylus paradoxus (Travassos, 1918) Boulenger, 1926, are equal in length (vs. vestibular branches unequal in size; see Fig. 16), and the cephalic inflation is divided into 2 regions (vs. cephalic inflation simple in structure; see Figs. 17, 18; Travassos, 1921; Durette-Desset, 1985). Finally, the synlophe at anterior region in A. paradoxus possesses 7 cuticular ridges, 2 of them highly developed and located laterally, instead of only 2 well-developed and dorsal cuticular ridges present in $T$. delicatus (Figs. 1, 4). At midbody region, $A$. paradoxus has 19 small ridges (Durette-Desset and Pinto, 1977), whereas in Tadaridanema the synlophe maintains the arrangement described for the anterior region (Figs. 2, 3, 5).

\section{DESCRIPTION}

\section{Tadaridanema delicatus (Schwartz, 1927) n. gen., n. comb.}

Description: Based in 31 specimens (7 males and 26 females).

Synlophe: Oriented ventral to dorsal; ridges in both sexes arising just posterior to cephalic inflation. Both males and females possess only 2 dorsal cuticular ridges in anterior and midbody regions; posterior region of males also with 2 dorsal ridges, but small in size (Figs. 1, 2, 7-10). Females with 4 ridges of similar size, 2 dorsal and 2 ventral, at prevulvar level. At postvulvar region, synlophe without ventral ridges. Caudal extremity without ridges.

Male: Length 2.7-3.6 mm [3 mm $\pm 0.4, \mathrm{n}=6]$ (3.5). Maximum diameter 56-87.5 $[71.7 \pm 12.6, \mathrm{n}=6](99.1)$ at midbody. Cephalic inflation 35-45.5 [43.1 $\pm 4.7, \mathrm{n}=6](42.5)$ long by $24.5-35[29.1 \pm$ $3.6, \mathrm{n}=6](28.3)$ wide. Distance from anterior end to nerve ring 129.5$161[147.8 \pm 14.3, \mathrm{n}=4]$ and to excretory pore $157.5-203[184.3 \pm$ $16.5, \mathrm{n}=6]$. Esophagus length 283.5-329 [310.9 $\pm 19.2, \mathrm{n}=6](255)$ by $24.5-35[29.1 \pm 3.6, \mathrm{n}=6](28.3)$ wide at base. Spicules equal in size, 154-192.5 [167.4 $\pm 15.8, \mathrm{n}=6](170)$ length; alated and simple in structure; distal tip pointed. Gubernaculum well developed and cuticularized, located dorsal to spicules, 38.5-52.5 [46.6 $\pm 5.7, \mathrm{n}=6]$ length by $7-10.5[7.5 \pm 1.4, \mathrm{n}=6]$. Genital cone present. Bursa with 2 large lateral lobes; prebursal papillae not observed. Arrangement of bursal rays 2 and 3 identical in both lobes; rays 2-6 arising from a common stem. Rays 2 and 3 curved, ray 2 larger than 3. Rays 4, 5, and 6 straight, with striated cuticle, diverging in origin. Rays 4 and 6 shorter than ray 5 . Dorsal ray short, splitting into 2 symmetrical rays (9 and 10); ray 9 always shorter than ray 10. Ray 8 long and slender, arising near base of dorsal ray.

Female: Didelphic. Length 4.15-6.3 mm [5.2 mm $\pm 0.5, \mathrm{n}=25]$ (5.2). Maximum diameter 77-154 [122.7 $\pm 19.5, \mathrm{n}=25](166.4)$ at medium level. Cephalic inflation 38.5-66.5 [55.5 $\pm 6, \mathrm{n}=25]$ long by $42-63[48.3 \pm 4.8, \mathrm{n}=25]$ wide. Distance from anterior end to nerve ring $175-217[190.4 \pm 16.1, \mathrm{n}=19]$ and to excretory pore $199.5-$ 
1

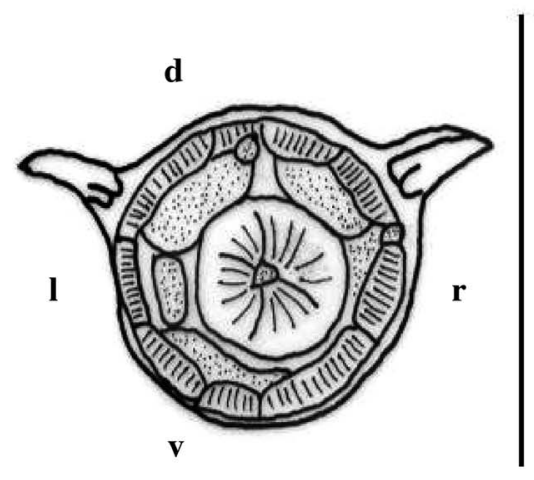

2

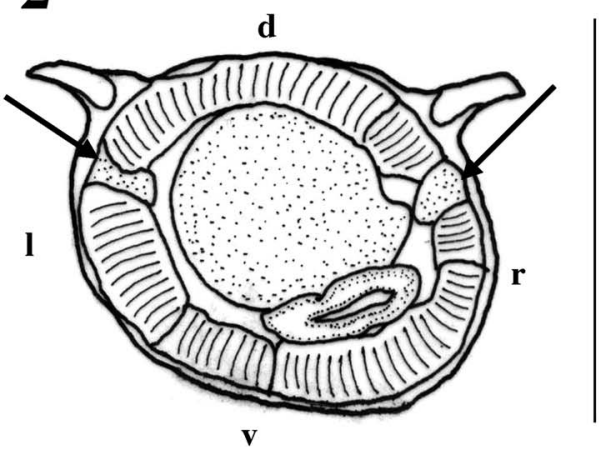

4

d

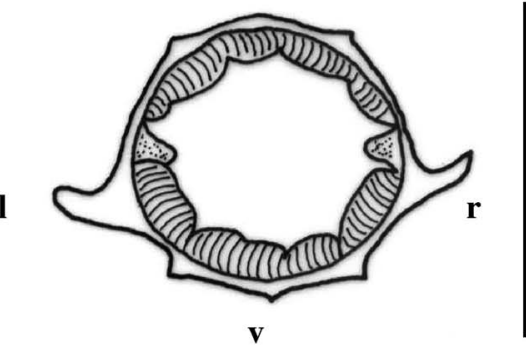

5

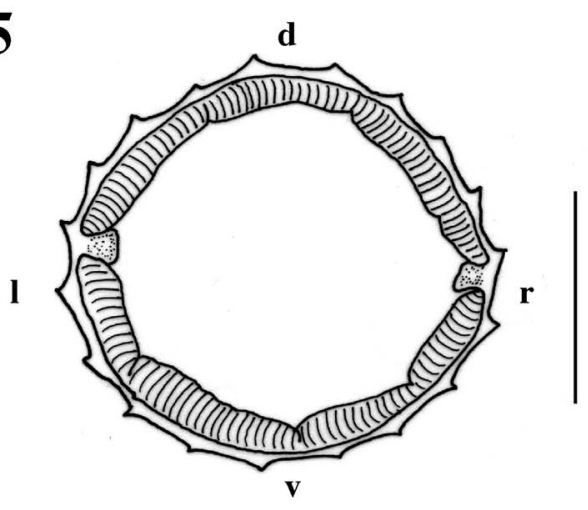

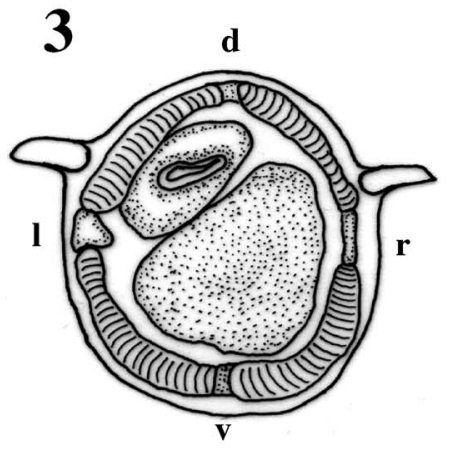

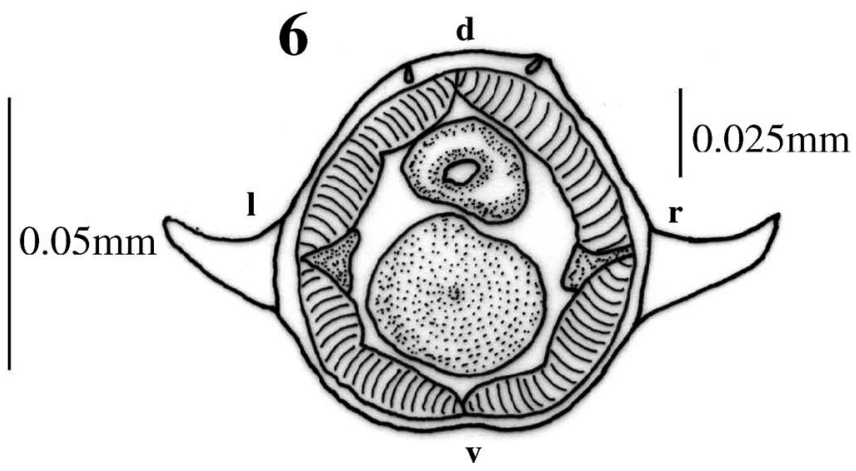

FiguRES 1-6. Synlophe of Tadaridanema delicatus (Schwartz, 1927) n. gen., n. comb. (1-3); Anoplostrongylus paradoxus (4, 5) after DuretteDesset and Pinto, 1977; and Bradypostrongylus panamensis (6) after Guerrero, 1982). Cross section at $(\mathbf{1}, \mathbf{4})$ esophageal level and $(\mathbf{2}, \mathbf{3}, \mathbf{5}, \mathbf{6})$ midbody level. Orientation of figures: $d$, dorsal; v, ventral; r, right; 1 , left. The arrow indicates the lateral cords. Bar $=0.1 \mathrm{~mm}$.

$290.5[228.4 \pm 49.9, \mathrm{n}=23]$. Esophagus length 350-406 [383.1 \pm $22.5, \mathrm{n}=25]$ (304.6) by 38.5-56 [43.8 $\pm 4.4, \mathrm{n}=25]$ (31.8) wide at base. Postequatorial vulva opening over a knoll; 938-1,701 [1,227.7 \pm $189.8, \mathrm{n}=22]$ from caudal extremity. Vagina vera length 59.5-105 $[78.5 \pm 14.3, \mathrm{n}=20]$; vestibule $178.5-262.5[206.5 \pm 29.5, \mathrm{n}=23]$ long, with branches unequal in size, anterior longer than posterior; anterior sphincter and infundibulum 45.5-70 [52.9 $\pm 9.4, \mathrm{n}=25](49.5)$ and $63-164.5[101.1 \pm 36.5, \mathrm{n}=10]$ long, respectively; posterior sphincter and infundibulum 35-87.5 [52.3 $\pm 9.7, \mathrm{n}=25]$ (53.1) and
70-87.5 [77 $\pm 7, \mathrm{n}=5]$ (77.9) long, respectively. Eleven eggs measured; $70-73.5,[70.9 \pm 2.2]$ (70.8) long by $42-52.5[47 \pm 3.6](48.5)$ wide. Anus to tip of tail 63-101.5 [74.7 $\pm 11.2, \mathrm{n}=21](99.1)$.

\section{Taxonomic summary}

Type host: Unidentified bat.

Site of infection: Intestine.

Type locality: College Station, Texas. 

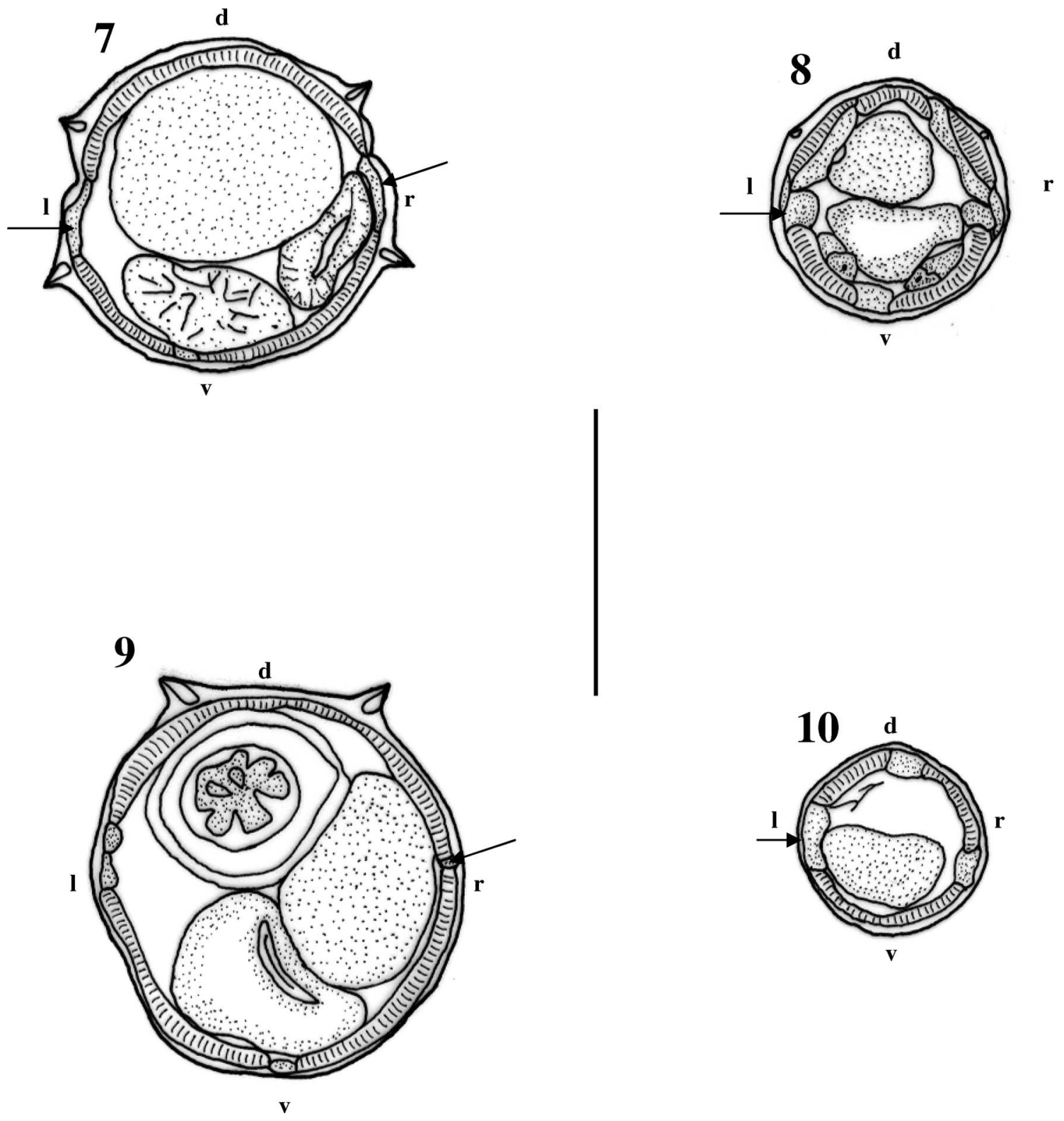

Figures 7-10. Tadaridanema delicatus (Schwartz, 1927) n. gen., n. comb., a parasite of Tadarida brasiliensis mexicana from Mexico. Cross section of female at (7) anterior branch of ovejector level, (9) posterior branch of ovejector level, and (10) tail level. Cross section of male at (8) spicular level. Orientation of figures: $\mathrm{d}$, dorsal; $\mathrm{v}$, ventral; $\mathrm{r}$, right; 1 , left. The arrow indicates the lateral cords. Bar $=0.1 \mathrm{~mm}$.

Other hosts: Molossus ater Geoffroy, 1805; Tadarida brasiliensis mexicana (Sassure, 1860).

Other localities: Mexico: Fábrica la Constancia, Nombre de Dios (ND), Durango State, $23^{\circ} 51^{\prime} \mathrm{N}, 104^{\circ} 51^{\prime} \mathrm{W}$; Cueva de la Boca (CB), Santiago, Nuevo León State, $25^{\circ} 26^{\prime} \mathrm{N}, 100^{\circ} 06^{\prime} \mathrm{W}$; Río Salado, Zapotitlán de las Salinas (RS), Puebla State, $18^{\circ} 20^{\prime} \mathrm{N}, 97^{\circ} 28^{\prime} \mathrm{W}$; Sinaloa; Iglesia de Guadalupe Garzarón, Concepción del Oro (CO), Zacatecas State, $24^{\circ} 37^{\prime} \mathrm{N}, 101^{\circ} 25^{\prime} \mathrm{W}$. USA: Berkeley, Alameda County, California; Florida; New Orleans, Louisiana; Carlsbad caverns and Ney cave, New Mexico; Frio and Braken caves and Crosbyton, Texas.

Prevalence: $\mathrm{ND}=5$ of 31 infected $(16.1 \%) ; \mathrm{CB}=5$ of 27 infected $(18.5 \%) ; \mathrm{RS}=6$ of 12 infected $(50 \%) ; \mathrm{CO}=10$ of 28 infected $(35.7 \%)$

Specimens analyzed: Holotype male and allotype USNPC 027138; Vouchers: RS: CNHE 3856-3859; ND: CNHE 3863; CB: CNHE 3861 , 3862; CO: CNHE 3860 and 4725; HWML 37516, 37517, and 37518; USNPC 05486 and 054861.

Synonyms: Anoplostrongylus delicatus Schwartz, 1927; Molinostrongylus (Anoplostrongylus) delicatus (Schwartz, 1927) Travassos, 1937.

\section{DISCUSSION}

Anoplostrongylus delicatus was transferred by Travassos (1937) to Molinostrongylus without discussing the reasons for such a decision; Durette-Desset and Chabaud (1975) rejected this proposal and retained it in Anoplostrongylus despite the absence of a cephalic inflation characteristic of the type species for this genus. This species cannot be included in Molinostrongylus because of the absence of important diagnostic traits (i.e., numerous cuticular spines on inner surface of bursa, rays 3 and 4 close together throughout their length, ray 2 shorter than 3 , and synlophe with ridges not oriented from ventral to dorsal side); in addition, species of Molinostrongylus parasitize exclusively Old World bats (Durette-Desset, 1983). On the basis of the revision of the type material of $A$. delicatus (USNPC 

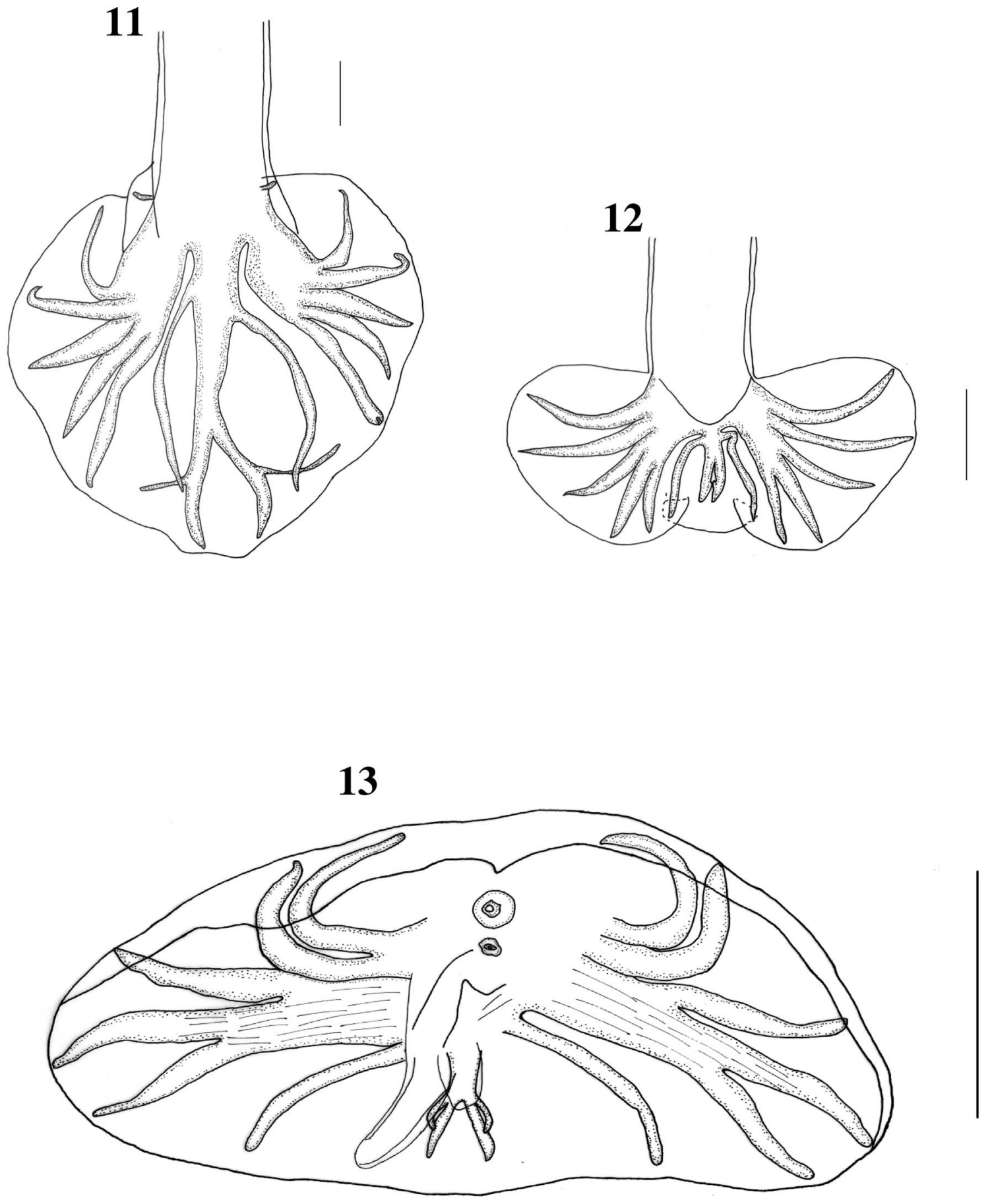

FiguREs 11-13. Males of Bradypostrongylus inflatus after Travassos, 1937 (11); Anoplostrongylus paradoxus after Travassos, 1921 (12); and Tadaridanema delicatus (Schwartz, 1927) n. gen., n. comb. (13) showing caudal bursa. Bar = $0.1 \mathrm{~mm}$.

027138) and in new specimens from T. b. mexicana from Mexico, we recommend that this species be transferred to Tadaridanema, as Tadaridanema delicatus (Schwartz, 1927) n. comb.

\section{ACKNOWLEDGMENTS}

We thank Laura del Castillo, Ada Ruíz, Saúl Aguilar, Reyna Lara, Roxana Acosta, Jorge Servín, Gerardo López, and Eduardo Catalán for their help during field and laboratory work. We also thank Livia León for her help in bat identification. Financial support was provided by
Programa de Apoyo a proyectos de Investigación e Innovación Tecnológica, Dirección General de Apoyos del Personal Académico (PAPIITUNAM) grants IN215796 and IN214599 to J. B. Morales-Malacara, Facultad de Ciencias, UNAM.

\section{LITERATURE CITED}

Boulenger, C. L. 1926. Report on a collection of parasitic nematodes mainly from Egypt. IV. Trichostrongylidae and Strongylidae. Parasitology 18: 86-100.

CAIN, G. D. 1966. A survey of the parasites of five species of bats. 

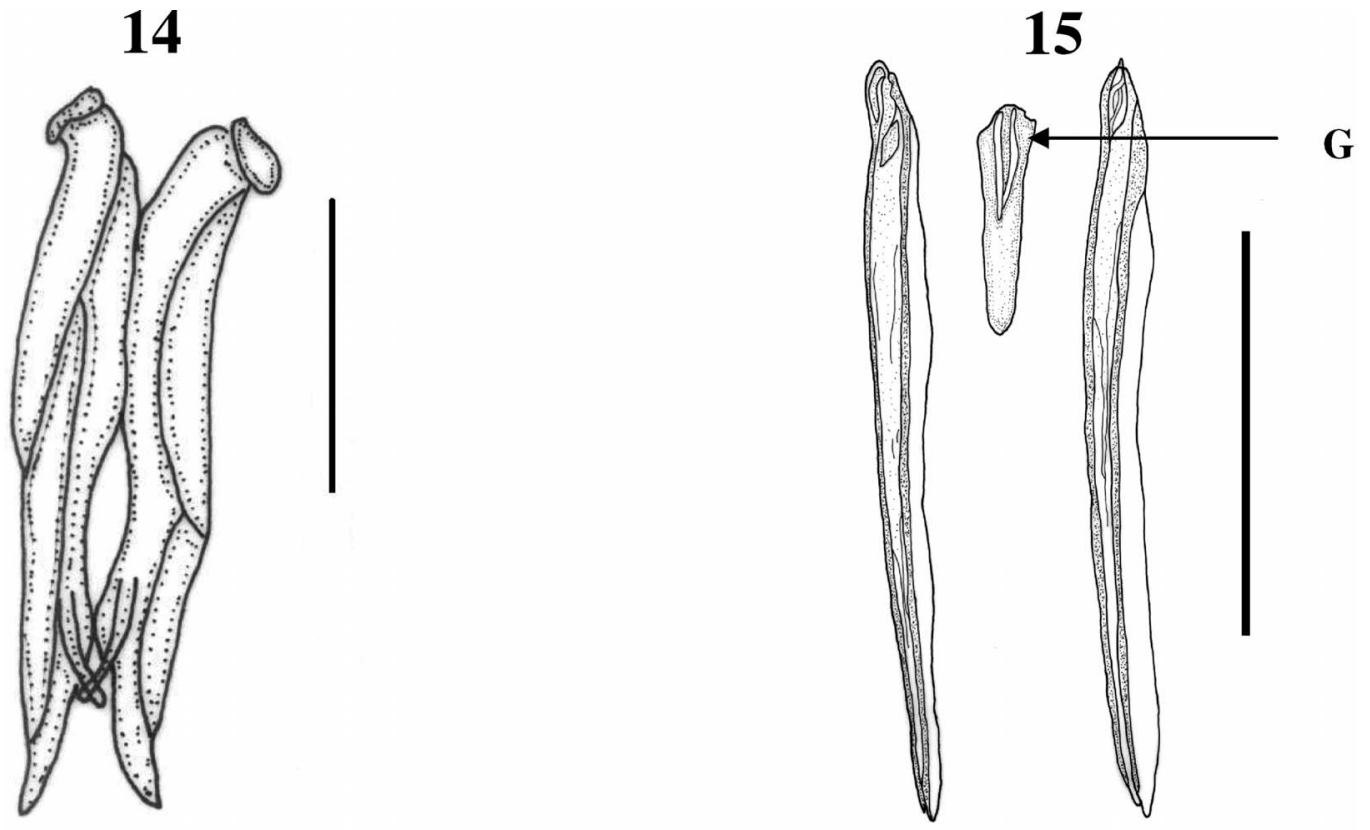

16

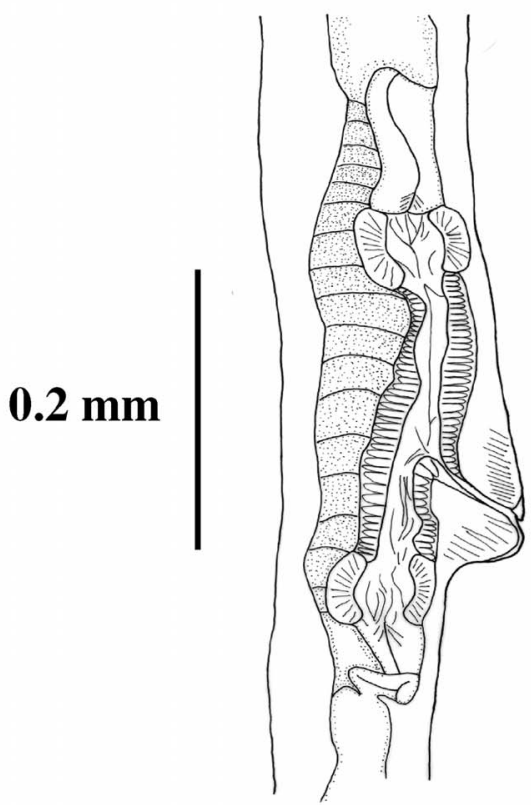

FiguRES 14-16. Spicules of Bradypostrongylus inflatus (14) after Travassos, 1937, and Tadaridanema delicatus (Schwartz, 1927) n. gen., n. comb. (15) and ovejector region of T. delicatus (16). $\mathrm{G}=$ gubernaculum. Bar $=0.1 \mathrm{~mm}$.

Helmith parasites of bats from Carlsbad Caverns, New Mexico. Journal of Parasitology 52: 351-357.

, AND E. H. STUDIER. 1974. Parasite helminthes of bats from southwestern United States and Mexico. Proceedings of the Helminthological Society of Washington 41: 113-114.

Chitwood, B. G. 1938. Some nematodes from the caves of Yucatan. Carnegie Institution of Washington Publication 491: 51-66.

Durette-Desset, M. C. 1983. Keys to genera of the superfamily Tri- chostrongyloidea, volume 10. In $\mathrm{CIH}$ key to the nematode parasites of vertebrates, R. C. Anderson and A. G. Chabaud (eds.). Commonwealth Agricultural Bureaux, Farnham Royal, Bucks, U.K., p. $1-86$.

1985. Trichostrongyloides nematodes and their vertebrate hosts: Reconstruction of the phylogeny of a parasitic group. Advances in Parasitology 24: 239-306.

, AND A. G. ChaBaud. 1975. Nématodes Trichostrongyloidea 
17

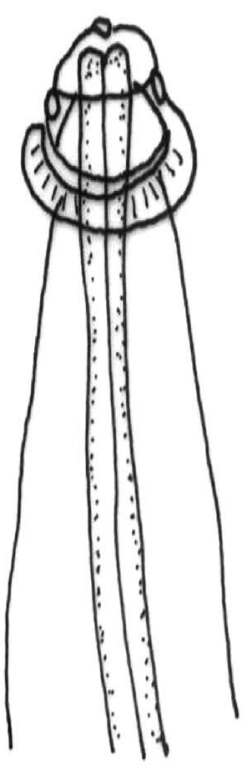

18

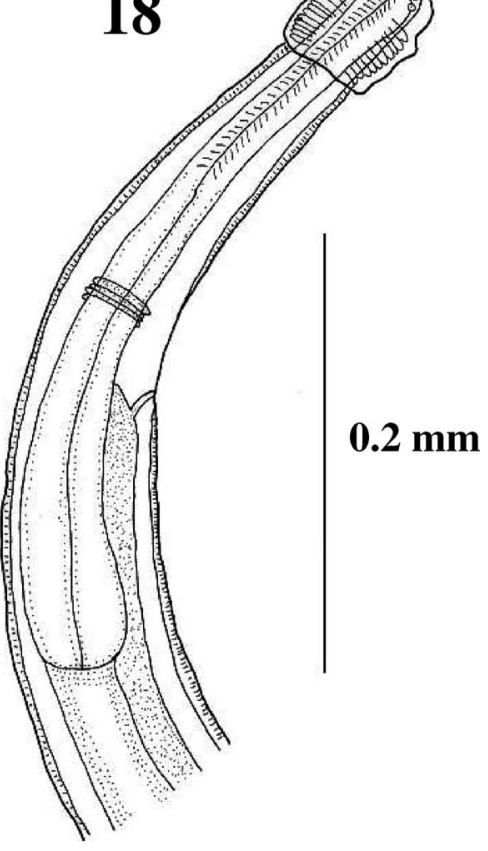

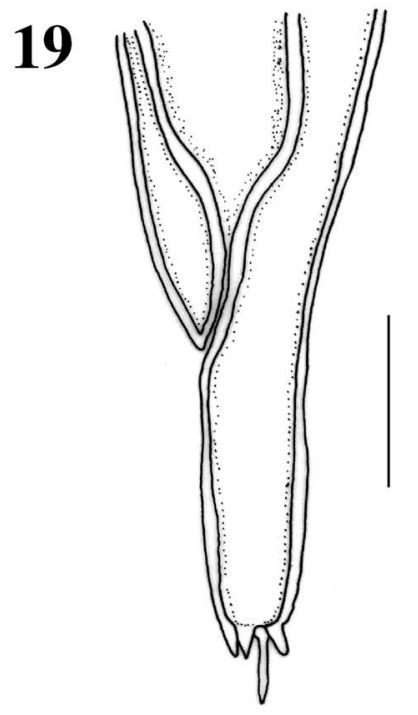

20

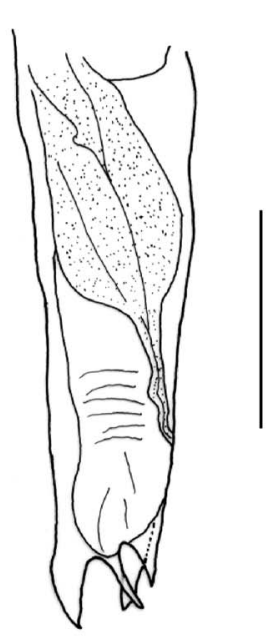

FiguRES 17-20. Females of Anoplostrongylus paradoxus (17) after Travassos, 1921, and Tadaridanema delicatus (Schwartz, 1927) n. gen., $\mathrm{n}$. comb. (18) showing cephalic inflation; females of Bradypostrongylus inflatus (19) after Travassos, 1937, and T. delicatus (20) tail with an ending tip surrounded by 3 conical cuticular processes. Bar $=0.1 \mathrm{~mm}$.

parasites de Microchiroptères. Annales de Parasitologie 50: 303337.

, AND R. M. PINTO. 1977. Nouvelles données morphologiques sur des nématodes Trichostrongyloides des collections de l'Institut Oswaldo Cruz. Bulletin du Museum National d'Histoire Naturelle 326: $755-764$.

, AND C. VAUCHER. 1996. Molostrongylus acanthocolpos gen. n., sp. n., (Nematoda, Trichostrongylina, Molineoidea) parasite de $\mathrm{Mo}$ lossops temmincki (Chiroptera, Molossidae) au Paraguay. Revue Suisse de Zoologie 103: 905-913.

GuERRERO, R. 1982. Trichostrongyloidea (Nematoda) parásitos de mamíferos silvestres de Venezuela. I. Los géneros Bradypostrongylus Price, 1928; Longistriata Schulz, 1926 y Durettestrongylus n. gen. Acta Biológica Venezuelica 11: 111-131. 
Guzmán-Cornejo, C., L. García-Prieto, G. Pérez-Ponce de León, And J. B. Morales-Malacara. 2003. Parasites of Tadarida brasiliensis mexicana (Chiroptera: Molossidae) from arid regions of Mexico. Comparative Parasitology 70: 11-25.

JAMESON, D. K. 1959. A survey of the parasites of five species of bats. Southwestern Naturalist 4: 61-65.

Lent, H., AND J. F. TeiXeIRA DE Freitas. 1938. Pesquisas helminthologicas realisadas no Estado do Pará. IV. Trichostrongylidos de mammiferos. Memorias do Instituto Oswaldo Cruz 33: 363-380.

MARTIN, D. R. 1976. New host and distribution records of helminth parasites of the Mexican free-tailed bat, Tadarida brasiliensis, from Texas and Louisiana. Proceedings of the Helminthological Society of Washington 43: 85-86.

ORTLEPP, R. J. 1922. A new trichostrongyle genus from an armadillo, Euphrectus villosus. Annals and Magazine of Natural History 9: 413-421.

PÉREZ-Vigueras, I. 1935. Torrestrongylus torrei, n. gen., n. sp., parásito de Chiroptera. Memorias de la Sociedad Cubana de Historia Natural 9: 57-58.

1941. Nota sobre el género Histiostrongylus Molin, 1861. Revista de Medicina Tropical y Parasitología, Habana 7: 67-72.

Price, E. W. 1928. New helminth parasites from Central American mammals. Proceedings of the United States National Museum 73: $1-7$.

SANDGRound, J. H. 1929. Some new parasitic nematodes from Yucatan (Mexico), including a new genus of strongyle from cattle. Bulletin of the Museum of Comparative Zoölogy 69: 515-524.

Schulz, R. S. 1926. Zur Kenntnis der Helminthenfauna der Nagetieri der Union S.S.R. 1. Subordo Strongylata: 1. Fam. Trichostrongylidae Leiper, 1912. Trudy Gosudarsrtvo Institut Ékspert Veterinarii 4: 5-32.

SCHWARTZ, B. 1927. A new parasitic nematode from an unknown spe- cies of bat. Proceedings of the United States National Museum 71: $1-4$.

Teixeira de Freitas, J. F., And J. M. MendonçA. 1959. Novo gênero de "graphidiinae" Travassos, 1937 (Nematoda, Strongyloidea). Revista Brasileira de Biologia 19: 387-392.

Travassos, L. 1921. Contribuções para o conhecimiento da fauna helmintolojica brasileira. XIII. Ensaio monográfico da familia Trichostrongylidae Leiper, 1909. Memorias do Instituto Oswaldo Cruz 13: $5-135$.

. 1928. Trichostrongylidae do Tamandua tetradactyla. Boletin Biologico 11: 23-40.

. 1935a. Alguns novos generos e especies de Trichostrongylidae. Revista de Medicina e Chirurgia do Brasil 43: 345-361.

- 1935b. Contribuição ao conhecimento dos Trichostrongylidae. Annales da Academia Brasileira de Ciencias 7: 355-360.

1937. Revisao da familia Trichostrongylidae Leiper, 1912. Monographias do Instituto Oswaldo Cruz, Rio de Janeiro, Brazil, 512 p.

1950. Contribuição ao conhecimento dos Trichostrongylidae de Tamandua tetradactyla (L.). (Nematoda). Anales del Instituto de Biología, Universidad Nacional Autónoma de México 20: 251269.

Vaucher, C., And M. C. Durette-Desset. 1986. Trichostrongyloidea (Nematoda) parasites de chiropteres Neotropicaux. 1. Websternema parnelli (Webster, 1971) n. gen. n. comb. et Linustrongylus pteronoti n. gen. n. sp., parasites de Pteronotus au Nicaragua. Revue Suisse de Zoologie 93: 237-246.

Voge, M. 1956. A list of nematode parasites from California mammals. American Midland Naturalist 56: 423-429.

WolfGAng, R. W. 1954. Studies on the endoparasitic fauna of Trinidad mammals. X. Parasites of Chiroptera. Canadian Journal of Zoology 32: $20-24$ 